\title{
Species Diversity and Abundance of Dragonflies and Damselflies (Odonata: Insecta) in and around Panvel, Navi Mumbai, Maharashtra (India)
}

\author{
Santosh P. Supanekar *, Mayur S. Naik, Leena N. Meshram, Anil G. Rokade \& Prabhakar R. Pawar \\ Mahatma Phule Arts, Science \& Commerce College, Panvel, Navi Mumbai, India \\ DOI: 10.29322/IJSRP.11.05.2021.p11345 \\ http://dx.doi.org/10.29322/IJSRP.11.05.2021.p11345
}

\begin{abstract}
Insects belonging to the order Odonata are ecological indicators and studies of insects show that, certain species exhibit high association with particular ecological conditions. Panvel is one of the fast-changing metro city in Navi Mumbai, Maharashtra, India, due to ongoing construction of Navi Mumbai International Airport (NMIA), rampant urbanization, industrialization and unplanned development have resulted into ecological disturbances and habitats fragmentation. Literature review suggest that no baseline data is available with respect to Odonata, particularly of dragonflies and damselflies. Hence present study is undertaken. 15 species of Odonates representing 2 suborders, 2 families and 2 subfamilies. Recorded Odonates belongs to families Libellulidae \& Coenagrionidae and species of family Libellulidae are found to be more abundant in the study area.
\end{abstract}

Index Terms- Biodiversity, Damselflies, Dragonflies, Odonata, Panvel, Species diversity

\section{INTRODUCTION}

$\mathrm{D}$ ragonflies and damselflies (Order - Odonata) are predatory insects, they having elongated body, large eyes, extended wings and predominantly found across the fields, meadows, forest, ponds, rivers etc. (Manwar, et al., 2012) [1]. Odonata appeared about 250 million years ago during the Carboniferous period, and modern families of these insects date from the upper Jurassic and Cretaceous periods (150-60 million years ago) (Shende and Patil 2013) [2]. Odonates are found in 5,952 species worldwide, with 474 species and 50 subspecies in India belonging to 142 genera and 18 families. (Subramanian, 2014) [3].

Odonates having long, slender abdomen; large globular eyes, often making up a large portion of the head; short antennae; and long wings, which have a conspicuous nodus and usually a pterostigma. Odonates are responsive to changes in ecosystems, atmosperic temperature, and weather conditions, making them strong indicators of environmental changes. (Tiple, 2012) [4]. Odonata present in all kinds of habitats along the habitat permanent gradient ranging from permanent running waters and lakes to small temporary rain pools (Corbet, 1999) [5]. They show some preferences to specific habitats and their distribution is very much involved in various microhabitats (Sheldon \& Walker, 1998) [6].
Maharashtra State present at central-west India \& due to its unique geographical position having a Odonata species rich states. Some species can withstand a wide range of environmental factors, while others are extremely vulnerable (Chovanec and Waringer, 2001[7]; Schindler et al., 2003[8]; Chovanec et al., 2004[9]; Ameilia et al., 2006[10]; Smith et al., 2006[11]). In to the Western Ghats of India the Odonata are habitat sensitive so, they are restricted to a narrow ecological space (Subramanian 2007[12]; Subramanian et al. 2011[13]).

Due to increased anthropogenic activities in and around Panvel, terrestrial fauna particularly diversity of insects is depleting day by day (Meshram et al. 2021[14]; Pawar et al. 2020[15]) It is the need of us to study Odonates of the area for baseline documents. Hence the present study is undertaken to record species diversity and abundance of dragonflies and damselflies from Panvel, Navi Mumbai.

\section{Materials AND MethodS}

Study area: Navi Mumbai is essentially a satellite township on Maharashtra's west coast. The Maharashtra government created it in 1971 as a new urban township in Mumbai. It had a population of 1,119,477 people according to the 2011 Census of India. Panvel is a node of Navi Mumbai city and is located in Maharashtra's Raigad district in the Konkan zone. Panvel is located near the Panvel Creek, which flows into Thane creek. The Kalundre River flows through the city's south-west region and empties into Panvel Creek. Panvel is a densely populated city due to its proximity to Mumbai, with a population of 180,464 (Census India 2011). It's part of the Mumbai Metropolitan Area. Panvel is located on the Panvel Creek's banks. It is also surrounded on two sides by mountains. The Panvel creek (Lat $18^{\circ} 58^{\prime} 26.895^{\prime \prime} \mathrm{N}$ to $18^{\circ} 59^{\prime} 58.432^{\prime \prime} \mathrm{N} \& 7^{\circ} 1^{\prime} 43.74 " \mathrm{E}$ to $73^{\circ} 6^{\prime} 48.269^{\prime \prime}$ E) is a 7-kilometer-long tributary of Thane creek (Fig. 1). The creek is distinguished by extensive mud flats, sparse mangrove vegetation, and less rocky stretches. The marshy areas and mud flats dominate the majority of the creek.

Study Location: Waterbodies, grasslands, and paddy fields have been chosen for this study. These sites were chosen based on their strategic locations and various anthropogenic activities.

Sampling \& Identification: The present study was carried out from June 2019 to May 2020. The study sites were 
surveyed monthly. Sampling was done by manually and only insect photography was done by the DSLR camera (Nikon d3500) in their natural habitat. The species were identified using standard key for identification. Identification was carried out with available standard taxonomic literature Fraser (1933[16], 1934[17], 1936[18]), Subramanian (2005)[3], and Subramanian (2014)[19].

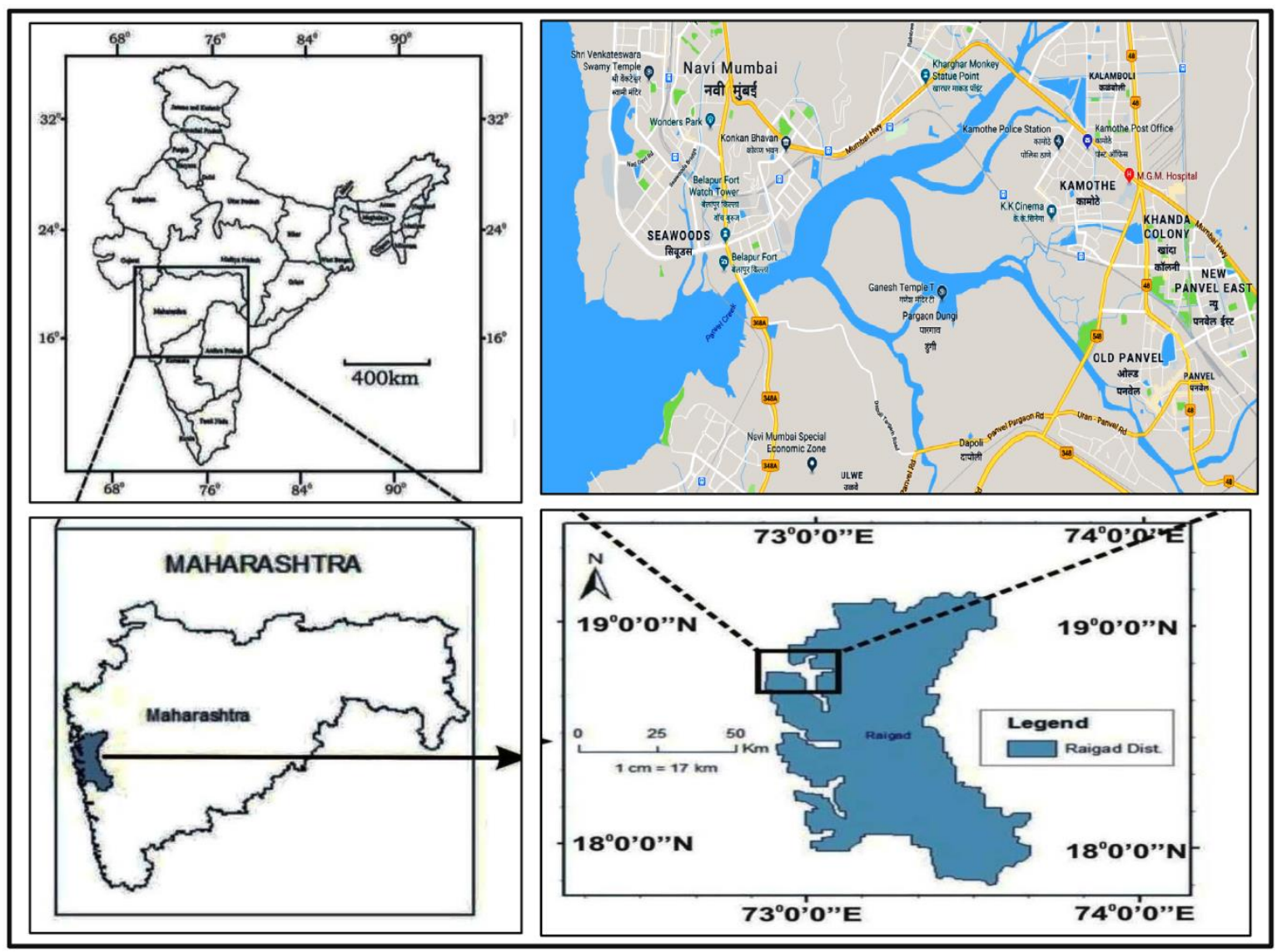

Fig. 1. Location map of study area representing vicinity of Panvel City (Source: Google Earth).

\section{RESULTS AND DISCUSSION:}

In present investigation 15 species of order Odonata consisting 02 suborder, 02 family and 02 subfamily are recorded (Table 1). The families Libellulidae \& Coenagrionidae are identified and the Libellulidae family is dominating within this study area. In this family comprises total 14 species (95\% of total species) and Coenagrionidae family have only one species $(05 \%$ of total species). Among suborder Anisoptera (Dragonflies), total 12 species of Odonata such as Orthetrum sabina sabina (Drury), Crocothemis servilia servilia (Drury), Pantala flavescens (Fabricious), Aethriamanta brevipennis, Brachydiplax sobrina, Acisoma panorpoides, Orthetrum chrysis, Neurothemis fulvia, Brachythemis Contaminata, Rhodothemis rufa, Cratilla lineata, and Neurothemis tullia belonging to family Libellulidae and 03 species such as Ceriagrion coromandelianum (Brauer), Ischnura senegalensis and Paragomphus lineatus belonging to family Coenagrionidae.

Species dominance of Odonata may be attributed to the presence of marshy areas, shrubs and wetland. Abundancy of species Brachythemis contaminata suggests that the water quality of water bodies is bad and it can be also assumed that pollution

This publication is licensed under Creative Commons Attribution CC BY.

http://dx.doi.org/10.29322/IJSRP.11.05.2021.p11345 from study area may too helped in distribution of this species. Study reports that Brachythemis contaminata is a dragonfly of polluted water and it can be seen abundantly where sewage is discharged (Kulkarni and Subramanian 2013) [20]. It is reported that the dragonflies and damselflies are ideal model insects for the investigation of the impact of the environmental warming and climate change due to its trophical evolutionary history and adaptations to temperate climate (Hassall et. al., 2008)[21].

Study on diversity patterns of Odonata of Maharashtra province can give an idea about the changing climatic condition and its effect on surrounding vegetation. Prasad (1996)[22] has been published the first exhaustive checklist of Odonata of Maharashtra State. Study on diversity patterns of Odonata can give an idea about the changing climatic condition due to the anthropogenic activities and its effect on surrounding vegetation.

\section{Conclusion:}

The ecosystem in and around the Panvel city is degrading at an alarming rate. In coming few years, area around Panvel will be dominated by intense industrialization and urbanization. In such circumstances, day by day all types of pollution are increasing and its adverse effect can see on the diversity of animals. Establishing the current checklist of Odonata needs an effort to gather species presence data across an extensive landscape. This checklist is 
likely to get modified as more data flow in across the State. Overexploitation of vegetation \& grassland, affect the ecosystem and it get disturb so, the species diversity will be push toward the threshold of extinction. This is a preliminary study to know the numbers of species and to study the natural habitat disturbed by anthropogenic activities going on in and around the Panvel City.

\section{REFERENCES}

[1] [1] Manwar, N. A., Rathod P. P., \& Raja I. A. 2012. Diversity and abundance of Dragonflies and Damselflies of Chatri Lake Region, in Pohara Malkhed Reserve Forest, Amravati, Maharashtra (India) International Journal of Engineering Research and Applications Vol. 2, 521523.

[2] [2] Shende V. A, \& K. G. Patil 2013. Diversity of dragonflies (Anisoptera) in Gorewada International Bio-Park, Nagpur, Central India; Arthropods, 2(4): 200-207

[3] [3] Subramanian, K. A., \& Sivaramkrishnan K. G. 2005. Habitat and microhabitat distribution of stream insect communities of Western Ghats. Current Science, 89: 976-987

[4] [4] Tiple A. D. 2012. Dragonflies and Damselflies (Odonata: Insecta) of the AchanakmarAmarkantak Biosphere Reserve, in Chhattisgarh and Madhya Pradesh, Biotechnol. Bio. Sci., 2(1): 97-102.

[5] [5] Corbet, P. S. 1999. Dragonfly Behaviour and Ecology of Odonata. Harley Books, Colchester, England, 829

[6] [6] Sheldon, G. \& Walker, K. E. 1998. Spatial distribution of littoral invertebrates in the lower Murray-Darling River System., Australia. Mar .Freswat. Res 49:171- 182.

[7] [7] Chovanec A. \& Waringer J. 2001. Ecological integrity of river-floodplain systems- assessment by dragonfly surveys (Insecta: Odonata). Regul. River 17 (4-5):493-507.

[8] [8] Schindler M, Fesl C, \& Chovanec A. 2003. Dragonfly associations (Insecta: Odonata) in relation to habitat variables: a multivariate approach. Hydrobiologia 497(1):169-180.

[9] [9] Chovanec A, Waringer J, Rajj R, Laister G. 2004. Lateral connectivity of a fragmented large river system: assessment on a macroscale by dragonfly surveys (Insecta: Odonata). Aquat. Conser. - Marine and Freshw. Ecosyst. 14:163-178.

[10] [10] Ameilia Z. S., Che Salmah M. R., Abu Hassan A. 2006. Distribution of Dragonfly (Odonata: Insecta) in the Kerian River Basin, Kedah-Perek, Malaysia. USU Repository. $14 \mathrm{p}$.

[11] [11] Smith J, Samways M. J., \& Taylor S. 2006. Assessing Riparian Quality Using Two Complementary Sets of Bioindicators. Biodiversity and. Conservation, 16 (9):2695- 2713

[12] [12] Subramanian, K. A. 2007. Endemic odonates of the Western Ghats: habitat distribution and conservation, pp. 257-271. In: Tyagi, B.K. (ed.). Odonata: Biology of Dragonflies. Scientific Publishers, Jodhpur, India
[13] [13] Subramanian, K. A., Kakkassery F. \& Nair M.V. 2011. The status and distribution of dragonflies and damselflies (Odonata) of the Western Ghats, 63-72

[14] [14] Meshram L. N., Supnekar S. P., Patil R. B. \& P. R. Pawar. 2020. Asian Journal of Advances in Research 4(3): 6-15

[15] [15] Pawar P. R., Rokade A. G., Supnekar S. P., Meshram L. N., Pawar N. B. \& U. V. Gavhane, 2020. Diversity and Distribution of Snakes in Adjoining Areas of Panvel, Navi Mumbai, West Coast of India, International Journal of Zoological Investigations Vol. $\quad 6$, No. 2, 289300

[16] [16] Fraser, F. C. 1933. The fauna of British India including Ceylon and Burma. Odonata, vol. I. Taylor and Francis Ltd., London, United Kingdom.

[17] [17] Fraser, F. C. 1934. The fauna of British India including Ceylon and Burma. Odonata, vol. II. Taylor and Francis Ltd., London, United Kingdom.

[18] [18] Fraser, F. C. 1936. The fauna of British India including Ceylon and Burma. Odonata, vol. III. Taylor and Francis Ltd., London, United Kingdom.

[19] [19] Subramanian, K. A. 2014. A checklist of Odonata (Insecta) of India. Zoological survey of India, Kolkata, WB. pp. 1-31.

[20] [20] Kulkarni A. S., Subramanian K. A. 2013. Habitat and seasonal distribution of odanata (Insecta) of Mula and Mutha river basins, Maharastra. Journal of threatened taxa.; $\quad$ 5(7):4084-4095.

[21] [21] Hassall C, Thompson D. J., Harvey I. F. 2008. Latitudinal variation in morphology in two sympatric damselfly species with contrasting range dynamics (Odonata: Coenagrionidae). European Journal of Entomology.105:939-944.

[22] [22] Prasad M. 1996. An account of the Odonata of Maharashtra State, India. Rec. Zool. India. 95: $305-327$

\section{AUTHORS}

First Author - Santosh P. Supanekar, Mahatma Phule Arts, Science \& Commerce College, Panvel, Navi Mumbai, India Second Author - Mayur S. Naik, Mahatma Phule Arts, Science \& Commerce College, Panvel, Navi Mumbai, India

Third Author - Leena N. Meshram, Mahatma Phule Arts, Science \& Commerce College, Panvel, Navi Mumbai, India Fourth Author - Anil G. Rokade, Mahatma Phule Arts, Science \& Commerce College, Panvel, Navi Mumbai, India Fifth Author - Prabhakar R. Pawar, Mahatma Phule Arts, Science \& Commerce College, Panvel, Navi Mumbai, India

Corresponding author: sankam23@gmail.com

Table 1: Checklist of Odonata species from in and around Panvel City.

\begin{tabular}{|l|l|l|l|l|}
\hline Order & Suborder & Family & Subfamily & Scientific name \\
\hline \multirow{3}{*}{ Odonata } & Anisoptera & \multirow{3}{*}{ Libellulidae } & - & $\begin{array}{l}\text { Orthetrum sabina sabina } \\
\text { (Drury, 1773) }\end{array}$ \\
\cline { 3 - 5 } & & & - & $\begin{array}{l}\text { Crocothemis servilia servilia } \\
\text { (Drury, 1773) }\end{array}$ \\
\cline { 3 - 5 } & & & & \\
\hline
\end{tabular}




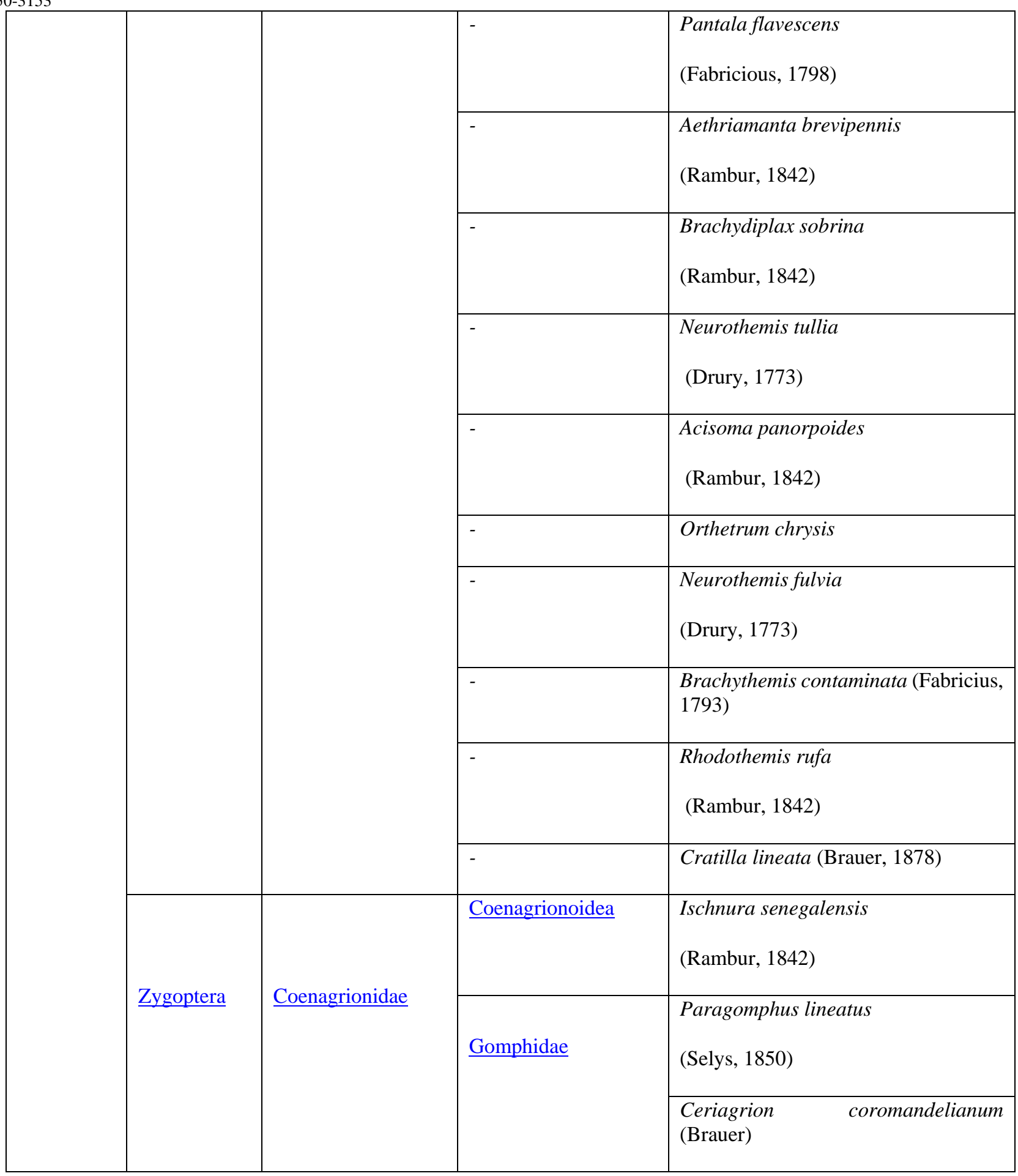



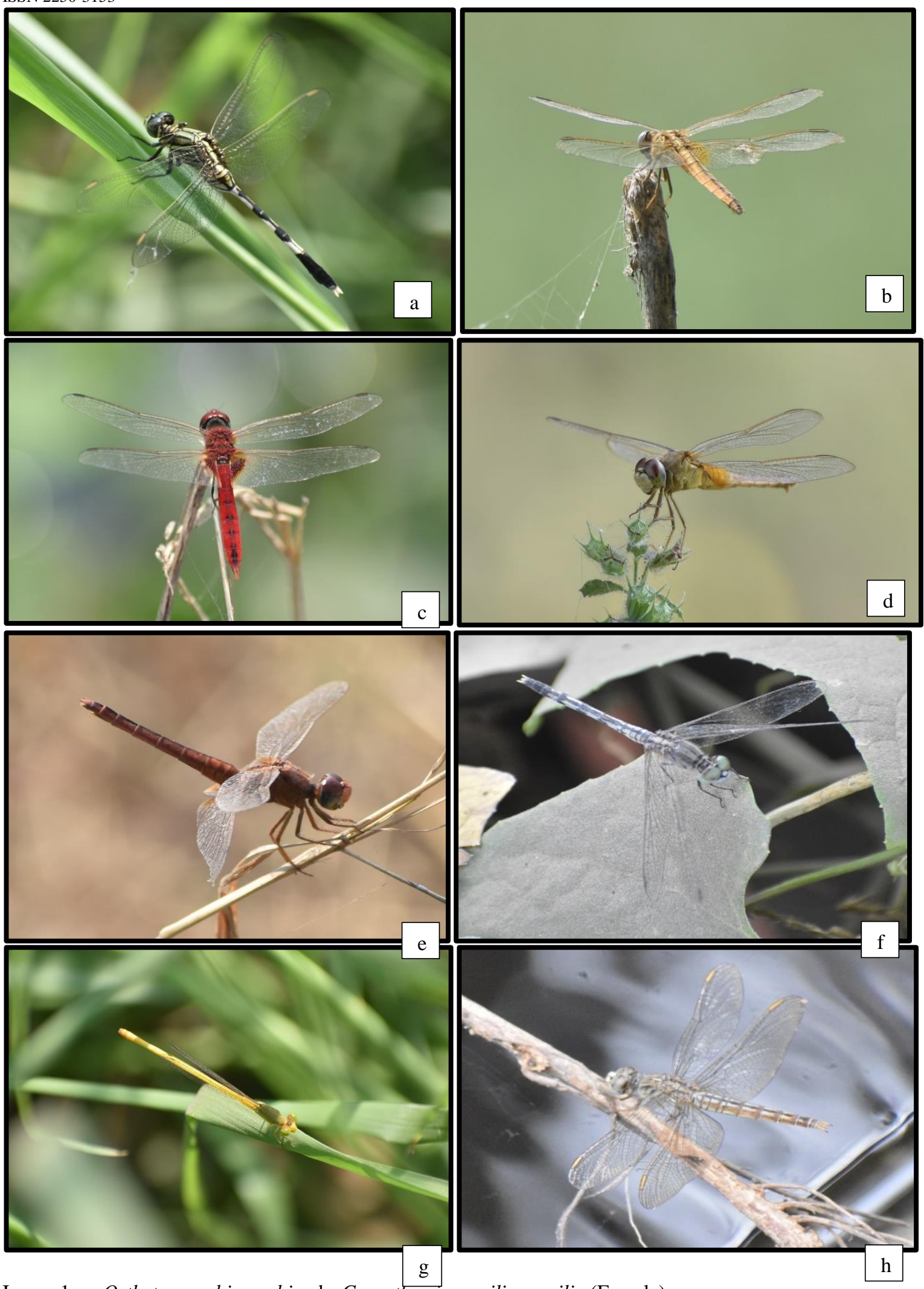

Image 1. a- Orthetrum sabina sabina b- Crocothemis servilia servilia (Female)

c- Crocothemis servilia servilia (Male) d- Pantala flavescens e- Aethriamanta brevipennis

f- Brachydiplax sobrina g- Ceriagrion coromandelianum h- Acisoma panorpoides

This publication is licensed under Creative Commons Attribution CC BY.

http://dx.doi.org/10.29322/IJSRP.11.05.2021.p11345 


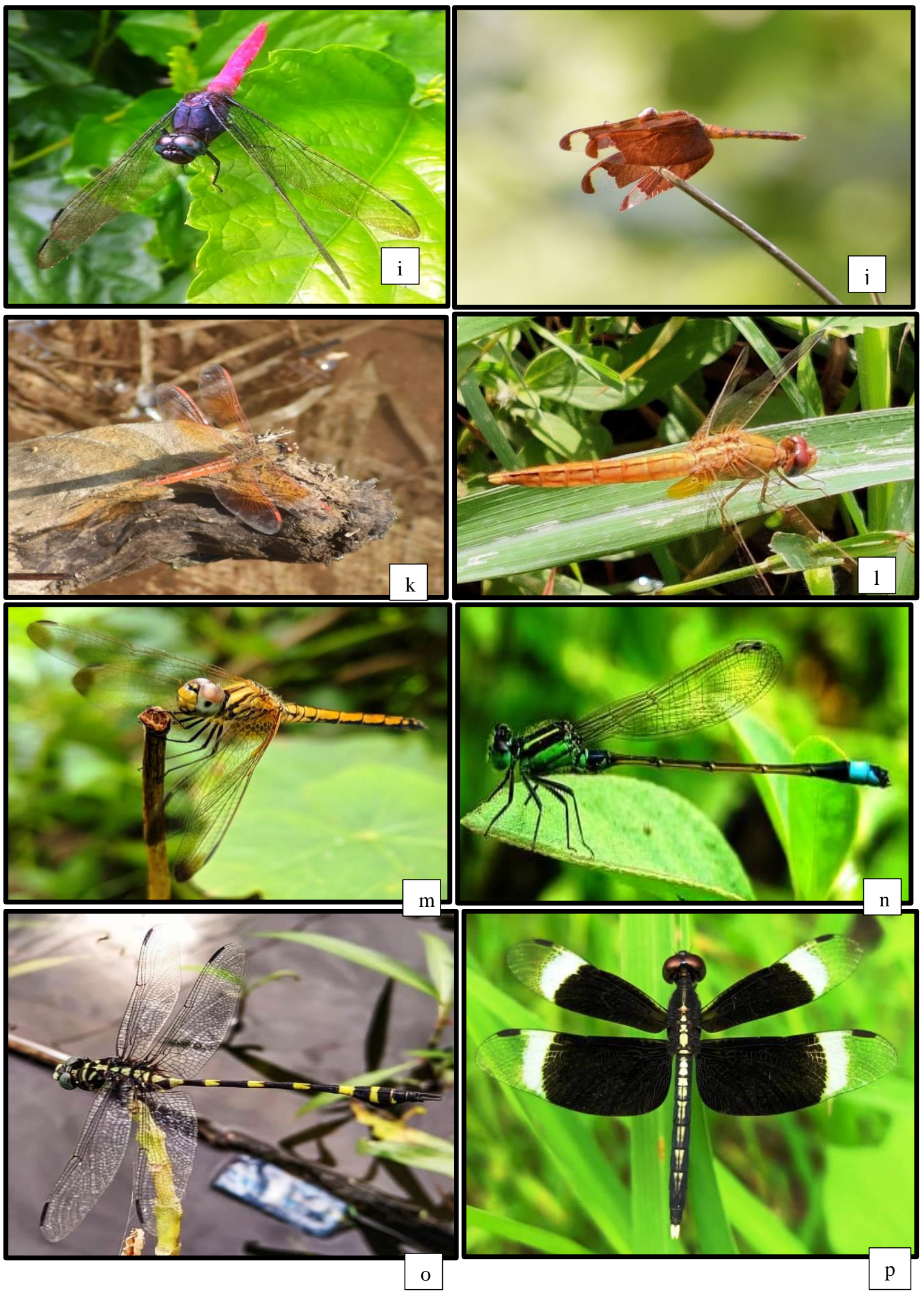

Image 2: i- Orthetrum chrysis j- Neurothemis fulvia k- Brachythemis contaminata

1- Rhodothemis rufa m- Cratilla lineata n- Ischnura senegalensis o- Paragomphus lineatus

\section{p- Neurothemis tullia}

This publication is licensed under Creative Commons Attribution CC BY

http://dx.doi.org/10.29322/IJSRP.11.05.2021.p11345 
International Journal of Scientific and Research Publications, Volume 11, Issue 5, May 2021 